\title{
ANALISIS PENGENDALIAN INTERN ATAS PENERIMAAN KAS PADA PT. MANDALA MULTIFINANCE, TBK CABANG MANADO
}

\author{
Gratia Patricia Ogi ${ }^{1}$, Sifrid S. Pangemanan ${ }^{2}$, Winston Pontoh ${ }^{3}$ \\ 1,2,3 Jurusan Akuntansi, Fakultas Ekonomi dan Bisnis, Universitas Sam Ratulangi, Jl. Kampus Bahu, Manado, \\ 95115, Indonesia \\ E-mail: gratiaogi05@gmail.com
}

\begin{abstract}
In a business activity, both large and small companies the goal obtained is the maximum profit in order to maintain the business. To achieve these objectives, it is necessary to have an Inter Control System. The object of research is PT. Mandala Multifinance, Tbk Manado branch engaged in vehicle transportation services. This study discusses to analyze the internal control system specifically for cash receipts at PT. Mandala Multifinance, Tbk Manado Branch. The research method used is descriptive qualitative. The results showed that the Internal Control System at PT. Mandala Multifinance, Tbk Manado branch has well had a Company Internal Policy (KIP) which is implemented to avoid fraud when receiving company cash.
\end{abstract}

Keywords: analysis; lease; internal control; cash receipts; PT. Mandala Multifinance

\section{PENDAHULUAN}

Tujuan dari pengendalian internal adalah untuk menjaga kekayaan organisasi, mengecek ketelitian dan keandalan dalam akuntansi, dan mendorong dipatuhinya kebijakan manajemen (Mulyadi, 2010). Menurut Mulyadi (2010), sistem pengendalian internal terhadap penerimaan kas yang meliputi struktur organisasi, metode dan ukuran-ukuran yang dikoordinasikan perusahaan, selain itu unsur-unsur pokok sistem pengendalian intern meliputi: organisasi yang memisahkan tanggung jawab dan wewenang secara tegas, sistem otorisasi dan prosedur pencatatan, praktik yang sehat, dan karyawan yang mutunya sesuai dengan tanggung jawab.

Disamping itu, manajemen dituntut untuk menjaga keamanan harta milik perusahaan, mencegah serta menentukan kesalahan dan penggelapan. Walaupun kas bukan merupakan asset yang lebih penting dari aset lain yang manapun, yang nilai pasarnya sama, namun pemeriksaan atas kas sangat penting, diantaranya bahwa sebagian besar transaksi usaha melibatkan perkiraan kas atau berakhir dengan kas. Keadaan ini akan mendorong perusahaan untuk melakukan penataan pada sistem akuntansi penerimaan kas meliputi beberapa aspek yang saling berkaitan.

Permasalahan yang dihadapi dalam perusahaan semakin beragam khususnya terhadap kas, pada bidang ini ukuran kerawanan yang terjadi yaitu adanya ketidaktelitian penerimaan uang dari nasabah, hilangnya salah satu slip setoran, dan dokumen-dokumen lainnya. Maka diperlukan prosedur-prosedur pengendalian internal terhadap kas dan itu harus terdapat pemisahan tugas secara tepat, sehingga petugas yang bertanggung jawab mengenai transaksi kas dan penyimpanan kas tidak merangkap sebagai petugas pencatat transaksi kas. PT. Mandala Multifinance, Tbk Cabang Manado merupakan perusahaan pembiayaan yang terus berkembang. Sistem pengendalian internal menjadi sesuatu yang penting dalam perkembangan perusahaan. Hal ini disebabkan karena banyaknya kecurangan yang akan terjadi jika perusahaan tidak memiliki pengendalian terhadap resiko perusahaan yang mungkin terjadi. 
Pencatatan keuangan khususnya pada bagian penerimaan kas yang baik sangat penting karena menyangkut keberlangsungan perusahaan dalam menjalankan usaha untuk tetap ada dalam persaingan usaha yang semakin tinggi. Oleh karena itu dianggap penting untuk menganalisis bagaimana sistem pengendalian intern penerimaan kas pada PT. Mandala Multifinance, Tbk Cabang Manado dalam menjaga perusahaan dari Fraud atau Error dalam perusahaan.

\section{TINJAUAN PUSTAKA}

Menurut Rahayu dan Suhayati (2010), pengendalian internal adalah suatu proses yang dijalankan oleh dewan komisaris, manajemen, dan personel lainnya dalam suatu entitas yang dirancang untuk memberikan keyakinan memadai tentang pencapaian tujuan keandalan pelaporan keuangan, menjaga kekayaan dan catatan organisasi, kepatuhan terhadap hukum dan peraturan, efektivitas dan efisiensi operasi.

Menurut Krismiaji (2010), menjelaskan pengendalian internal adalah rencana organisasi dan metode yang digunakan untuk menjaga atau melindungi aset, menghasilkan informasi yang akurat dan dapat dipercaya, memperbaiki efisiensi, dan untuk mendorong ditaatinya kebijakan manajemen. Pengendalian internal bagi suatu perusahaan (terutama yang sudah go public) adalah merupakan suatu keharusan bersamaan dengan kewajiban audit laporan keuangan, direksi wajib memberikan pernyataan tentang kecukupan sistem pengendalian perusahaan yang dikelolanya serta model (framework) mana yang diadopsi (atau sepenuhnya didesain sendiri), dan wajib diaudit oleh auditor eksternal, pengendalian internal melaksanakan tiga fungsi penting, pengendalian untuk pencegahan (preventive control), pengendalian untuk pemeriksaan (detective control), dan pengendalian korektif (corrective control).

Menurut Elder et al. (2013), pengendalian internal adalah suatu proses yang dijalankan oleh dewan komisaris, manajemen, dan personel lain entitas yang didesain untuk memberikan keyakinan memadai tentang pencapaian tiga golongan tujuan berikut ini, keandalan pelaporan keuangan, efektivitas dan efisiensi operasi dan kepatuhan terhadap hukum dan peraturan yang berlaku perusahaan publik nonpublic maupun organisasi nirlaba diharuskan untuk memenuhi beragam ketentuan hukum dan peraturan.

Mulyadi (2016) mendefinisikan bahwa sistem pengendalian intern meliputi struktur organisasi, metode dan ukuran-ukuran yang dikoordinasikan untuk menjaga aset organisasi, mengecek ketelitian dan keandalan data akuntansi, mendorong efisiensi dan mendorong dipatuhinya kebijakan manajemen. Bodnar dan Hopwood (2006) menyatakan bahwa ada 5 (lima) unsur (komponen) pengendalian yang saling terkait, yaitu lingkungan pengendalian, penaksiran resiko, aktivitas pengendalian, dan pengawasan. Hery (2007) menyebutkan bahwa tujuan dari sistem pengendalian adalah:

1. Aset yang dimiliki oleh perusahaan telah diamankan sebagai mestinya dan hanya digunakan untuk kepentingan perusahaan semata, bukan untuk individu (perorangan) atau oknum karyawan tertentu. Dengan demikian, pengendalian internal diterapkan agar seluruh aset perusahaan dapat terlindungi dengan baik dari tindakan penyelewengan, pencurian, dan penyalahgunaan yang tidak sesuai dengan wewenangnya dan kepentingan perusahaan.

2. Informasi akuntansi perusahaan tersedia secara akurat dan dapat diandalkan, ini dilakukan dengan cara memperkecil risiko baik atas salah saji laporan keuangan yang disengaja (kecurangan) maupun yang tidak disengaja (kelalaian).

3. Karyawan telah mentaati hukum dan peraturan. Salah satu hal yang paling riskan dalam pengendalian internal adalah kecurangan yang dilakukan oleh karyawan (employee fraud). Kecurangan karyawan ini adalah tindakan yang disengaja dengan tujuan untuk memperoleh keuntungan pribadi. Contoh bentuk kecurangan karyawan yang sering 
dilakukan dan hampir selalu dijumpai pada sebagian besar perusahaan adalah melaporkan biaya perjalanan dinas dan penggantian pengobatan melebihi dari jumlah yang sesungguhnya dikeluarkan.

Tujuan pengendalian intern menurut Tunggal (2013), yaitu: (a) keandalan dan integritas informasi, dimana komponen pengendalian (informasi dan komunikasi) secara utuh menjelaskan dan mencakup tujuan tersebut; (b) ketaatan dengan kebijakan rencana dan prosedur organisasi, dimana komponen pengendalian (aktivitas pengendalian) menunjukan bahwa penetapan dan ketaatan yang diperkuat terhadap kebijakan dan prosedur untuk mempertahankan organisasi dalam jalur terhadap pencapaian tujuan; (c) mengamankan harta, pemakaian sumber daya yang ekonomis dan efisiensi, dan pencapaian tujuan dan sasaran yang ditetapkan; dan (d) kepatuhan terhadap hukum, regulasi, dan kontrak.

Kas dan setara kas menurut Ikatan Akuntan Indonesia (IAI) dalam Standar Akuntansi Keuangan (2009) menyatakan bahwa kas terdiri dari saldo kas (cash in hand) dan rekening giro. Yang dimaksud dengan kas (cash) meliputi uang logam, uang kertas, cek, giro, wesel, dan simpanan uang yang tersedia untuk ditarik kapan saja dari bank dan lembaga keuangan lainnya. Menurut Soemarso (2004), kas adalah segala sesuatu, baik yang berbentuk uang atau bukan, yang dapat tersedia dengan segera dan diterima sebagai pelunasan kewajiban pada nilai nominalnya. Kas menjadi asset yang paling mungkin untuk dicuri dan disalahgunakan oleh karyawan karena mudah dipindahtangankan. Selain itu, banyak transaksi baik langsung maupun tidak langsung mempengaruhi penerimaan atau pembayaran kas.

Weygandt et al. (2002) mengemukakan bahwa kas terdiri dari koin, uang kertas, cek, money order (wesel atau kiriman ditangan melalui pos yang lazim berbentuk draft bank atau cek bank), dan uang tunai di tangan atau simpanan di bank atau semacam deposito. Oleh karena itu perusahaan harus merancang dan menggunakan pengendalian yang dapat melindungi kas dan otorisasi transaksi kas. Menurut Smith dan Skousen (2000), sewa adalah kontrak yang mendapatkan syarat-syarat pengalihan hak pemakaian harta atau aset sewa oleh pemiliknya (lessor). Leasing dimanfaatkan secara luas dewasa ini sebagai suatu cara untuk memperoleh berbagai aset. Perorangan dapat menyewa rumah, kendaraan, alat-alat elektronik, alat-alat rumah tangga, perabotan dan hampir semua konsumsi lannya. Beberapa perjanjian sewa pada hakikatnya adalah perjanjian sewa, sementara yang lainnya sebenarnya adalah harta dengan kredit. Masalah utama bagi akuntan adalah apakah sewa ini harus dibukukan sebagai perjanjian sewa atau sesuai dengan bentuk hukumnya, atau sebagai pembelian harta yang mencerminkan adanya transaksi ekonomi. Pelealu dan Sabijono (2015) menunjukkan bahwa sistem informasi akuntansi khususnya penerimaan kas pada Rumah Sakit Ibu dan Anak (RSIA) Kasih Ibu telah sesuai dengan unsur pokok sistem informasi akuntansi yang dibuktikan dengan adanya pencatatan yang baik dan pengendalian internal yang memadai. Dolonseda dan Tinangon (2015) menemukan bahwa PT. Suramando telah menerapkan unsur-unsur pengendalian intern piutang usaha yang layak dan memadai, ditunjang dengan kebijakan dan prosedur yang ada. Pakadang (2013) menunjukkan bahwa penerapan sistem pengendalian intern penerimaan kas pada Rumah Sakit Gunung Maria baik walau masih terdapat beberapa aspek yang perlu diperbaiki.

\section{METODE PENELITIAN}

Dalam penelitian ini data yang digunakan adalah jenis data kualitatif yaitu data yang berbentuk uraian atas deskriptif yang diperoleh dari PT. Mandala Multifinance, Tbk Cabang Manado dimana data berupa pertanyaan- pertanyaan tentang sistem dan kinerja atas perusahaan. Penelitian dilaksanakan pada PT. Mandala Multifinance, Tbk yang beralamatkan di Jl. 14 Februari Lingkungan VII, Teling Bawah, Wenang, Kota Manado. Prosedur pengumpulan data dalam penelitian ini dilakukan dengan tahap-tahap yaitu wawancara, observasi, dan penelitian kepustakaan. 


\section{HASIL PENELITIAN DAN PEMBAHASAN}

\subsection{Hasil penelitian}

Dalam menghadapi persaingan dari perusahaan lain, pihak manajemen PT. Mandala Multifinance, Tbk menetapkan kebijakan pemberian kredit yang ringan dan proses yang cepat, serta persyaratan pembiyaan yang mudah. Prosedur pembiayaan kendaraan roda dua dari PT. Mandala Multifinance, Tbk adalah: (1) pemohon mengisi formulir permohonan pembiayaan; (2) pemohon melengkapi berkas pembiayaan, berupa: fotocopy Kartu Tanda Penduduk pemohon, Kartu Keluarga atau Akta Nikah Pemohon, Rekening Listrik/Rekening Air/Rekening air 3 bulan terakhir, dan Slip gaji/Surat Keterangan Usaha (SKU); (3) Kepala Surveyor meregistrasi data konsumen dan mencetak Order Survey; (4) Surveyor melakukan survey ke rumah pemohon setelah menerima Order Survey dari Kepala Surveyor; dan (5) Kepala Surveyor menerima hasil survey. Pemberian kredit diberikan pada konsumen yang lulus berdasarkan kriteria 5C, yaitu:

1. Character adalah data tentang kepribadian dari calon pelanggan seperti sifat-sifat pribadi kebiasaan-kebiasaannya, cara hidup, keadaan dan latar belakang keluarga maupun hobinya. Character ini untuk mengetahui apakah nantinya calon nasabah ini jujur berusaha untuk memenuhi kewajibannya (willingness to pay).

2. Capacity merupakan kemampuan calon nasabah dalam mengelola usahanya yang dapat dilihat dari pendidikannya, pengalaman mengelola usaha, dan sejarah perusahaan yang pernah dikelola (pernah mengalami masa sulit atau tidak, bagaimana mengatasi kesulitan). Faktor ini merupakan ukuran dari kemampuan dalam membayar (ability to pay).

3. Capital adalah kondisi kekayaan yang dimiliki oleh perusahaan yang dikelolanya. Hal ini biasa dilihat dari neraca, laporan laba rugi, strukur permodalan, rasio-rasio keuntungan yang diperoleh seperti return on equity dan return on investment. Dari kondisi ini dapat dinilai apakah layak calon pelanggan diberi pembiayaan dan beberapa besar pagu pembiayaan yang layak diberikan.

4. Collateral adalah jaminan yang mungkin bisa disita apabila ternyata calon pelanggan benar-benar tidak bisa memenuhi kewajibannya. Jaminan diperhitungkan paling akhir artinya bilamana masih ada suatu kesangsian dalam pertimbangan-pertimbangan yang lain, maka bisa menilai harta yang mungkin bisa dijadikan jaminan.

5. Condition dimana pembiayaan yang diberikan juga perlu mempertimbangkan kondisi ekonomi yang dikaitkan dengan prospek usaha calon nasabah karena bisnis tertentu sangat tergantung pada kondisi perekonomian dan oleh karena itu perlu mengaitkan kondisi ekonomi dengan usaha calon pelanggan.

\subsection{Pembahasan}

Lingkungan pengendalian merupakan unsur yang sangat penting dalam menunjang pembiayaan terlebih dalam pengelolaan penerimaan kas, oleh karena itu lingkungan pengendalian terdiri dari atau merupakan gabungan berbagai faktor dalam membentuk dan memperkuat aktifitas kebijaksanaan dalam prosedur tertentu. Lingkungan pengendalian pada PT. Mandala Multifinance. Tbk tercermin dalam perilaku setiap perusahaan, dimana PT. Mandala Multifinance. Tbk merupakan perusahaan yang bertujuan mencari laba untuk mencapai tujuan tersebut, organisasi merupakan salah satu faktor yang penting bagi perusahaan dalam menjadikan usahanya agar tujuan utama perusahaan dapat berjalan efektif dan efisien. Mengingat pentingnya suatu organisasi, maka diperlukan struktur organisasi yang merupakan lingkungan pengendalian yang dapat menunjang tercapainya tujuan utama perusahaan yang bersangkutan. Dengan adanya struktur organisasi ini akan lebih memudahkan pengelolaan perusahaan dan memungkinkan terlaksananya pengawasan atas semua kegiatan yang menyangkut semua fungsi didalam organisasi baik langsung maupun tidak langsung. 
Struktur organisasi dalam suatu perusahaan dapat memberikan suatu gambaran yang jelas mengenai fungsi, wewenang, dan tanggung jawab yang dimiliki oleh masing-masing bagian dan karyawannya. Stuktur organisasi yang ada pada PT. Mandala Multifinance, Tbk adalah struktur organisasi lini (line organization). Prosedur yang dijalankan perusahaan sebagai penaksiran risiko oleh manajemen, dimana pencatatan penerimaan kas terhadap pembiayaan kendaraan roda dua PT. Mandala Multifinance, Tbk terdiri dari: (a) Kasir; dan (b) dokumen yang digunakan. Dokumen untuk penerimaan kas meliputi buku catatan setoran setiap kali melakukan penyetoran dan slip pembayaran yang divalidasi dengan cap perusahaan. Aktivitas pengendalian dalam penerimaan kas dimulai saat konsumen datang ke kantor (kasir), dengan tujuan membayar angusuran motor, yang dilanjutkan dengan pemeriksaan data konsumen oleh kasir. Kasir melanjutkan dengan pemeriksaan kas konsumen. Data akan diferivikasi dan di-input ke dalam komputer. Dari proses ini, kasir akan mencetak slip pembayaran yang sudah divalidasi dengan cap perusahan dan tanda tangan kasir. Untuk pembayaran angsuran via Alfamart, Indomaret, dan Kantor Pos, slip pembayaran menjadi bukti valid pembayaran angsuran karena setiap pembayaran sudah terintegrasi langsung ke sistem PT. Mandala Multifinance, Tbk.

PT. Mandala Multifinance, Tbk. menyadari pentingnya aktivitas pengendalian yang andal dan efektif demi meminimalisir terjadinya kecurangan dan pencurian kas. Sehubungan dengan itu maka dibentuk Sistem Pengendalian Intern dalam bentuk Ketentuan Intern Perusahaan (KIP) untuk penerimaan kas. Sebagai perusahaan jasa pembiayaan, yang sebagian besar dari aset produktifnya berupa pembiayaan konsumen, maka semakin sehat aset produktif perusahaan, akan semakin besar kemampuan perusahaan menghimpun dana angsuran konsumennya, dan akhirnya akan semakin besar pula kemampuan perusahaan dalam pengembangan usahanya. Selanjutnya mengingat dana angsuran konsumen yang berhasil dihimpun jumlah nilainya cukup besar, maka pengelolaan dan perlakuannya perlu diatur dengan kebijakan internal perusahaan.

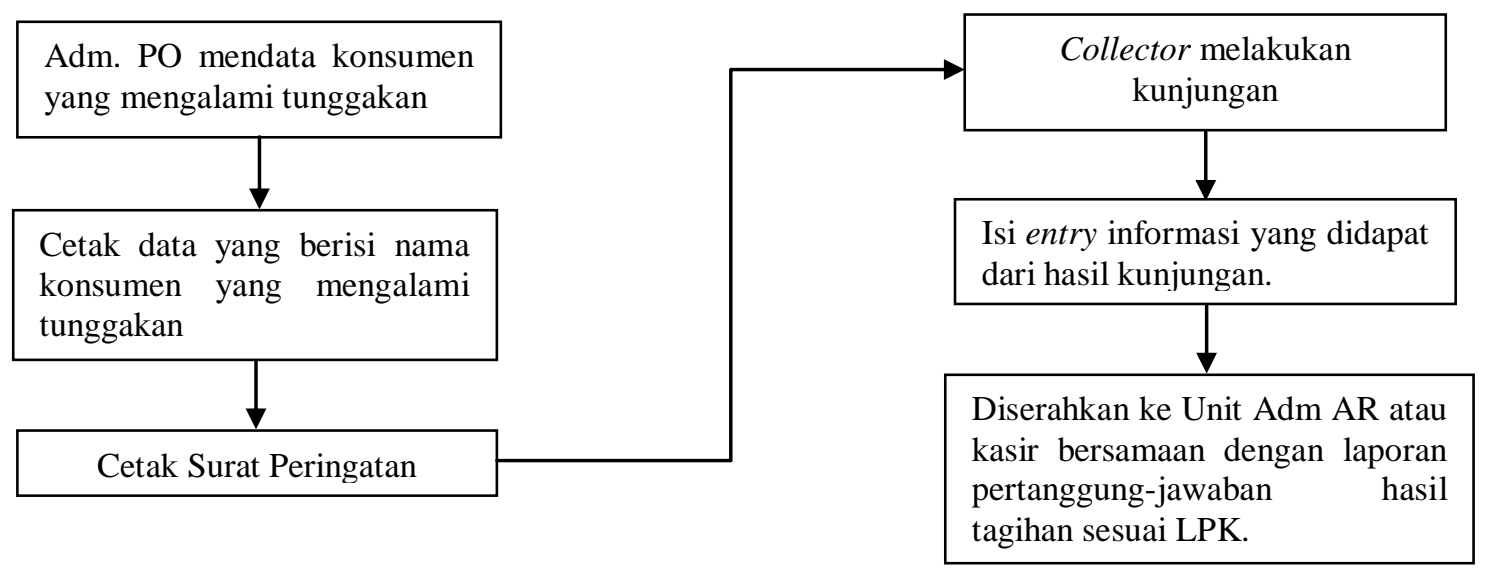

Gambar 1. Prosedur untuk konsumen yang mengalami kredit macet Sumber: Olahan data tahun, 2019

Berdasarkan Gambar 1, pada PT. Mandala Multifinance Cabang Manado, penerimaan kas dilakukan pada bagian kasir dan diinput dalam sistem akuntansi sehingga laporan keuangan terbentuk secara otomatis. Sistem informasi akuntansi yang sudah terkomputerisasi sangat baik dalam menunjang pengendalian internal untuk siklus penerimaan kas sehingga mencegah terjadinya kesalahan penyajian dalam pelaporan keuangan.

Pengawasan penerimaan kas pada PT. Mandala Multifinance, Tbk dikoordinir oleh Manajer Operasional, namun untuk spesifikasi pada piutang yang tak tertagih atau dalam biasa disebut kredit macet, pengawasan dilakukan oleh Koordinator Wilayah (Korwil). Korwil bertanggung jawab memantau setiap kinerja dari kolektor melalui Lembar Penagihan 
Kolektor (LPK). LPK berisi data konsumen yang didatangi kolektor serta menerangkan kondisi penagihan saat itu. Monitoring juga dilakukan dalam perusahaan ini, dimana adanya pemantauan (briefing) bagian divisi yang mempunyai bawahan. Sehingga baik dari level yang paling bawah sampai level paling atas ada yang memonitoring. Adanya audit internal juga merupakan salah satu unsur yang sangat penting dalam pengawasan dimana audit internal berfungsi untuk menilai kinerja serta memeriksa laporan keuangan perusahaan.

\section{KESIMPULAN DAN SARAN}

\subsection{Kesimpulan}

Pengendalian internal yang sangat penting untuk menghindari fraud pada penerimaan kas. Sistem pengendalian internal yang diterapkan pada PT. Mandala Multifinance sudah baik dengan adanya struktur organisasi yang dimiliki perusahaan menunjukan adanya lingkungan pengendalian yang diterapkan perusahaan. Untuk penaksiran risiko dalam melakukan suatu transaksi terlihat dari cara pembayaran konsumen hingga pengendalian untuk piutang. Diterapkannya aktivitas pengendalian yang terlihat dari adanya prosedur mencakup perancangan penerimaan kas yaitu Kebijakan Intern Perusahaan (KIP). Serta adanya sistem informasi akuntansi yang membantu perusahaan dalam menjalankan kegiatan operasionalnya dan aktivitas pemantauan dari setiap bagian yang mempunyai bawahan, sehingga setiap bagian ada yang mengawasi.

\subsection{Saran}

Beberapa saran yang dianggap perlu dalam usaha meningkatkan aktivitas perusahaan dan untuk mencapai tujuan yang telah ditetapkan perusahaan yaitu:

1. Guna menghindari dan mengurangi risiko proses sistem dalam komputer, maka sebaiknya pihak PT. Mandala Multifinace, Tbk memilih karyawan yang memiliki keahlian dalam mengoperasikan komputer agar proses kerja berjalan dengan lancar.

2. Kualitas sumber daya manusia perlu ditingkatkan demi kelancaran pembiayaan sampai pada penerimaan kas.

\section{DAFTAR PUSTAKA}

Bodnar, G. H., \& Hopwood W. S. (2006). Sistem informasi akuntansi, Edisi kesembilan. Yogyakarta: Penerbit Andi.

Dolonseda, G. A., \& Tinangon, J. J. (2015). Evaluasi pengendalian intern atas piutang usaha pada PT. Suramando (Distributor farmasi dan general supllier) di Manado. Jurnal EMBA: Jurnal Riset Ekonomi Manajemen dan Bisnis Akuntansi, 3(2), 468-475. https://ejournal.unsrat.ac.id/index.php/emba/article/view/8579.

Elder, R. J., Beasley, M. S., Arens, A., \& Jusuf, A. A. (2013). Jasa audit dan assurance (pendekatan terpadu adaptasi Indonesia). Jakarta: Salemba Empat.

Hery. (2007). Siklus akuntansi perusahaan. Jakarta: Graha Ilmu.

Ikatan Akuntan Indonesia. (2009). Standar Akuntansi Keuangan. Jakarta: Salemba Empat. Krismiaji. (2010). Sistem informasi akuntansi, Edisi ketiga. Yogyakarta: Unit Penerbitan dan Percetakan Sekolah Tinggi Ilmu Manajemen Yayasan Keluarga Pahlawan Negara.

Mulyadi. (2010). Auditing, Jilid I Edisi keenam. Jakarta: Salemba Empat.

Mulyadi. (2016). Sistem akuntansi, Edisi keempat. Jakarta: Salemba Empat.

Pakadang, D. (2013). Evaluasi penerapan sistem pengendalian internal penerimaan kas pada Rumah Sakit Gunung Maria di Tomohon. Jurnal EMBA: Jurnal Riset Ekonomi Manajemen dan Bisnis Akuntansi. 1(4), 213-223. https://ejournal.unsrat.ac.id/index.php/emba/article/view/2652. 
Pelealu, D. A., \& Sabijono, H. (2015). Analisis penerapan sistem informasi akuntansi penerimaan kas pada Rumah Sakit Ibu dan Anak Kasih Ibu Manado. Jurnal EMBA: Jurnal Riset Ekonomi Manajemen dan Bisnis Akuntansi, 3(2), 315-325. https://ejournal.unsrat.ac.id/index.php/emba/article/view/8535.

Rahayu, S. K., \& Suhayati, E. (2010). Auditing konsep dasar dan pedoman pemeriksaan akuntan publik. Yogyakarta: Graha Ilmu.

Smith, J. M., \& Skousen, K. F. (2000). Intermediate accounting, Volume Komprehensif, Edisi 9, Jilid 1. Jakarta: Erlangga.

Soemarso, S. R. (2004). Akuntansi: Suatu pengantar. Jakarta: Salemba Empat.

Tunggal, A. W. (2013). Pengendalian internal mencegah dan mendeteksi kecurangan. Jakarta: Harvarindo.

Weygandt, J. J., Kimmel, P. D., \& Kieso, D. E. (2002). Accounting principles, Fourth Edition. New York: Wiley \& Son Inc. 